\title{
PASTURE MANAGEMENT FOR HIGH PRODUCTION ON DAIRY FARMS
}

\author{
B. A. J. Sмiтн \\ Instructor in Agriculture, Department of Agriculture, \\ Hawera
}

Wiтn the targets announced by the Agricultural Development Conference, it is necessary to look closely at all methods of increasing production. While there is much scope for development of poorer country, and while this is perhaps the glamour way of increasing production, a tremendous increase can come by raising the production on fully-developed dairy farms. By increasing the stocking rate of dairy cows, production levels can be raised almost overnight, and, while initial costs for extra stock may be high, returns in the first year often cover these costs. The only other cost is perhaps for extra fertilizer, but this too is quickly recovered. Three years' trial work at the Waimate West Demonstration Farm, in South Taranaki, illustrate the basic principle: "More cows + more fertilizer = more butterfat $=$ more cash". This principle can be applied equally well to sheep and beef cattle properties. The Manaia farm at Waimate covers 90 acres of Egmont black loam, a freedraining derivative of Egmont andesitic ash. Rainfall varies, from 45 to 50 in. per year with dry periods common in summer and early autumn. Whole milk is produced for cheese factory supply.

A trial commenced in 1961 has the following objectives:

(1) The examination of the effects of phosphate compared with phosphate plus potash in terms of both butterfat and pasture production.

(2) The comparison of two rates of stocking with and without potash.

(3) The examination of the correlation, if any, between pasture and butterfat production.

\section{Trial Layout}

The farm area is 90 acres. Seventy-six acres are used for the trial-while-the-balance of 14 -acres, less ${ }^{-}$race,-buildings, etc., run replacement stock, twenty calves being reared annually. The seventy-six acre area is divided into four small independent and self-sunporting farmlets each with its own herd of 23 cows. Two farmlets are of 23 acres each

- one receives phosphate alone and the other phosphate 
and potash. The other two farmlets are both of $\mathbf{1 5}$ acres again, one receives phosphate and the other phosphate and potash.

The four treatments are shown in Table 1.

TABLE 1: TREATMENT OF FOUR FARMLETS IN TRIAL AREA

\begin{tabular}{|c|c|c|c|c|c|}
\hline Treatment & & $\begin{array}{l}\text { Area } \\
\text { acres) }\end{array}$ & $\begin{array}{l}\text { No. of } \\
\text { Cows }\end{array}$ & $\begin{array}{l}\text { Stocking Rate } \\
\text { (cow s/m.) }\end{array}$ & $\begin{array}{c}\text { Fertilizer } \\
(c w t / a c . / y r)\end{array}$ \\
\hline Low stock & & 23 & $\overline{23}$ & 1 & Super. 4 \\
\hline $\begin{array}{l}\text { Low stock }+ \\
\text { potash }\end{array}$ & 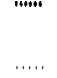 & 23 & 23 & 1. & $\begin{array}{l}\text { Super. } 4+ \\
\text { Potash } 2\end{array}$ \\
\hline High stock & num & 15 & 23 & $11 / 2$ & Super. 4 \\
\hline$\underset{\text { potash }}{\text { High stock }}+$ & & 15 & 23 & $11 / 2$ & $\begin{array}{l}\text { Super, } 4+ \\
\text { Potash } 2\end{array}$ \\
\hline
\end{tabular}

Phosphate is applied in one dressing each autumn as 44/46 superphosphate. Potash as the muriate is applied in split dressings, 1 cwt each spring and autumn. These fertilizer rates are not excessive in South Taranaki and the more progressive farmers apply higher rates with excellent results.

Cows remain in their herds and on their own farmlets at all times. They are milked in four herds by the same milkers in one shed.

\section{Butterfat Production}

Production for the last two seasons based on herd test figures is shown in Table 2.

\section{TABLE 2 : BUTTERFAT PRODUCTION} (lb fat/acre)

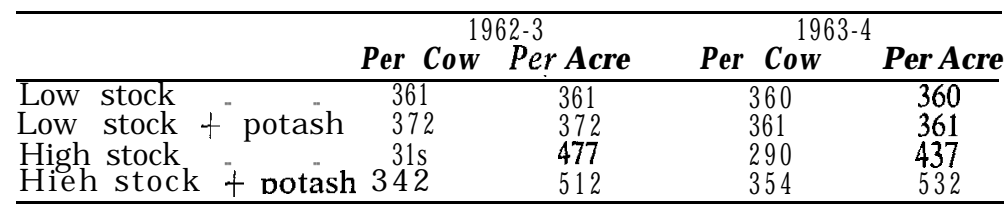

While the comparison between fertilizer rates indicates that only when stocked-up is potash payable, the purpose of this paper is to outline practices used to obtain over $500 \mathrm{lb}$ fat per acre in two successive years. It is proposed to deal mainly with these practices although some compari-, sons are necessary.

What then are the practices which-lead to $500 \mathrm{lb}$ butterfat per acre and what are the effects on pastures and stock? 
The first point of interest is the very small depression in the per cow production when an extra $1 / 2$ cow/ acre is grazed

some $7 \mathrm{lb}$ per acre. Thus the production from the extra $1 / 2 \mathrm{cow} /$ acre is a pure production increase.

Obviously, a high carrying capacity is necessary for high production. This involves a high degree of management skill and one must be prepared to punish both pastures and cows at times. Conditioning of cows to a lowered feed intake, and the farmer to a desire to increase production are both necessary. Given the incentive, the New Zealand farmer has the ability to reach the production levels shown in Table 2 and in South Taranaki several farmers are approaching 1 1/2 cows per acre.

\section{Pasture Management}

The four trial herds are maintained on grass and hay alone, with no crop grown and no bought-in supplements used. Artificial breeding has been used in the herd for the past ten years and while the cows are of good grade Jersey quality they have not been specially selected for dairy production. They are, in other words, a good slightly-betterthan-average grade herd.

Each herd grazes on its own farmlet of 13 paddocks rotationally, the length of the rotation depending on the feed supply. Grazing is not at any pre-determined pasture length. If feed is plentiful, a 12-hour rotation is used. If feed is short, the rotation is slowed down to a 24-hour or even a 36-hour one. If necessary, a paddock is divided in half temporarily to lengthen the rotation. An even level of feed intake is essential for high production. Violent fluctuations are reflected in daily production-generally in a downward trend.

\section{Hay Supplies}

Hay is cut from each farmlet and fed back only to the farmlet from which it was cut. Silage is not made and wintering is done equally well on hay as hay and silage.

Hay yields for 1963-4 are given in Table 3.

TABLE 3: HAY YIELDS, 1963-4

\begin{tabular}{lcc}
\hline & Area Cut & \\
\cline { 2 - 4 } & $($ Acres $)$ & Total Bätes \\
\hline Low stock + potash & 4.8 & 281 \\
Low stock + potash & 10.0 & 655 \\
High stock + potash & 2.1 & 125 \\
High stock + & 2.1 & 135 \\
\hline
\end{tabular}


This winter, the amount of hay -135 bales -has been ample for 23 cows, i.e., 6 bales of hay per cow, with good saved-pasture. In any case, with a high carrying capacity it is unlikely that much more hay can be saved.

It must be remembered that at Manaia there is a freedraining soil which aids wintering, and good seasonal pasture-growth, as is shown by data from long-term rate-ofgrowth measurements. Seasonal dry matter production was as follows ( 1949-56 average): Winter, 1,300 lb; spring, $2,800 \mathrm{lb}$; summer, $2,600 \mathrm{lb}$; autumn, 1,600 lb.

On a wet soil, wintering on saved-grass is a problem with small amounts of hay, but methods of wintering on such soils have been outlined at Grassland conferences in the $\mathrm{p}$ a $\mathrm{s} \mathrm{t}$.

\section{W intering}

As soon as cows are dried-off in mid-May, the culls are removed and each herd is confined to a single paddock and fed hay alone, under the Wallace system, for 5 to 6 weeks. All hay feeding is completed by mid-June. This winter, a paddock of 1 acre carried 20 cows for 5 weeks with a daily hay ration of 4 bales for 20 cows. Overfeeding of hay at this stage is wasteful, and if hay can be fed wastefully there is too much on hand; this is a sign of understocking.

On a free-draining soil the "sacrifice" area is bared, but not badly pugged. This year, to overcome the lag before such an area can be grazed again, 1 bushe per acre of Grasslands M anawa (short-rotation) ryegrass was oversown three days before the cows came out of the paddock. The seed was well-tramped in and established very well.

Three weeks before calving, each herd starts breakfeeding on saved-grass. Back-fencing is used to utilize feed to the maximum and to reduce pugging by restricting stock movement. No provision is made for water since stock do not appear to need it.

As cows calve, they form a milking herd on each farm and are break-fed saved-grass. Dry cows continue to be back-fenced.

Since the low rate of stocking is too low, the typical conditions which exist on most farms in mid- to late summer have been encountered. Grass runs to seedhead and becomes rank and unpalatable. Such areas must be topped and preferably baled. While this is sound practice, it is more productive to prevent such conditions occurring. 


\section{Pasture Production}

Pasture production is measured by cutting a frame in each paddock monthly. Table 4 gives results for 1962-3.

TABLE 4 : PASTURE, PRODUCTION, 1962-3

\begin{tabular}{|c|c|c|c|c|c|}
\hline & & & & & D.M.lb/acre \\
\hline $\begin{array}{l}\text { No potash } \\
\text { Potash } \\
\text { Low stock } \\
\text { High stock }\end{array}$ & 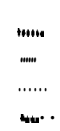 & $\begin{array}{l}\cdots \cdots \cdot \\
\cdots+\cdots \\
\cdots \cdots\end{array}$ & 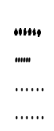 & $\begin{array}{l}\ldots+\cdots \\
\cdots+\cdots \\
\ldots \ldots . . \\
\ldots \ldots . .\end{array}$ & $\begin{array}{c}8,900 \\
11,000(+2,100) \\
10,400(-900) \\
9,500(-900)\end{array}$ \\
\hline
\end{tabular}

Surprisingly, less grass is grown under the higher rate of stocking, i.e., an increase in the stocking rate has not increased pasture production and it is obvious visually that less grass is always available to cows on the high stock farms. It is assumed, therefore, that these cows are used to a lower feed intake and have become conditioned to it. These stock utilize feed more efficiently as is shown in Table 5.

TABLE 5: UTILIZATION OF FEED ON HIGH-STOCK FARMS

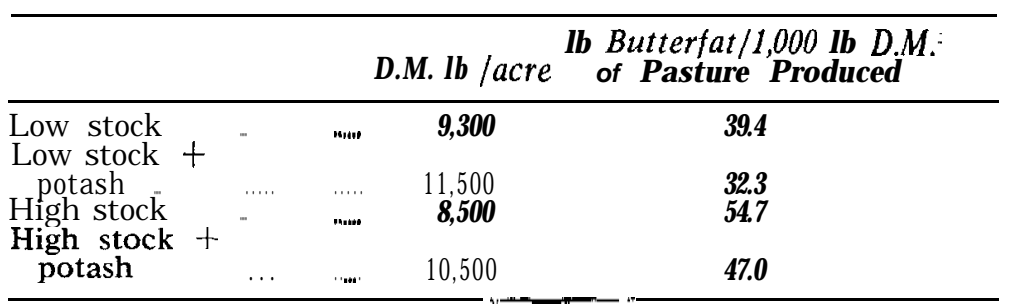

Pasture utilization is much more efficient at the higher rate of stocking. Pasture production levels for 1963-4 are comparable, with a decrease of $600 \mathrm{lb}$ between high- and low-stocking rates.

Pasture quality does not appear to be as important as pasture utilization. In other words, it is more productive to eat off all the grass grown than worry too much about the species-present 7 -It may-be-that, because-of-insufficient utilization, some of the newer grass species have not been given sufficient opportunity to prove themselves, and full use has not been made of their potential. If $500 \mathrm{lb}$ fat per acre is possible on pastures which are not of the best quality visually, what is the potential of the so-called highly- 
productive species bred and improved by Grasslands Division in the last 20 years? It is suggested that it is better to use fully the existing species before undertaking an expensive regrassing programme on any particular farm.

One could ask too, "What is a good pasture?" Is it one that looks good and has the correct balance of clovers to high-producing grass species, or is it a pasture which will produce butterfat?. Are management- and utilization of more value than pasture- quality?

\section{Stock $\mathrm{H}$ ealth}

Stock health shows very little variation. One Tb reactor has shown up since 1960. In 1963, nine cases of milk-fever were spread evenly through all herds. This year, milk-fever was prevalent in the district but 15 cases were again spread evenly over the four herds. Bloat appears more on the highstock herds, mainly because these cows graze a younger, more immature and clovery pasture. It can be satisfactorily controlled, however, by spraying. One can assume then, that disease is no greater problem when the stocking rate is increased.

High-stocked cows produce lighter calves but the difference is not significant. Mean butterfat tests show a very slight drop on high-stock herds-these herds have produced less butterfat from less total milk, but milk quality has not been affected.

Body liveweight shows remarkably little fluctuation a 5\% depression to high stocking noted in September, 1963, had disappeared by December.

\section{Stock Conditioning}

When the carrying capacity is raised, two important factors must be taken into account and both must be conditioned to the new environment.

First, the stock, and secondly, the farmer. The latter is by far the harder to condition. Dairy cows are highly intellligent animals and will, if possible, bluff the farmer at the slightest chance of success. How often does one hear the story, "I put the cows in that paddock and they stood and bellowed until I let them out into another paddock that they like"? This is pure bluff by cows and cannot be tolerated under high-stocking conditions.

In the first year of the trial, some difficulty was found in persuading cows that they could exist, let alone produce, 


\section{Pasture Management of Dairy Farms}

at $11 / 2$ cows per acre. After three years, these same cows are quite happy not only to exist but to produce at very high levels. Provided that the feed supply remains even, much less grass and hay can be used for production. A fluctuating or too great a supply of feed does more damage than too little. One'must be prepared for a slight drop in production until stock become accustomed to less feed and become more efficient at conversion.

Conditioning a farmer is much harder, and the mental barrier to increasing the stocking rate is a most difficult obstacle to overcome. Thoughts of cows bogged down in winter mud or starving in a summer drought loom large in his mind. In every district there are farmers -farming journals quote them frequently-who are prepared to show the way and have the courage to break through this barrier. Those who have done it invariably say, "The worst never happens anyhow".

Admittedly, the work at Manaia has been with small 23-cowherds, but the difficulties with a 100-cow herd should not be any greater.

One commercial herd in South Taranaki is already achieving both a high carrying capacity and high production. The farm area is 250 acres. Three years ago, it carried 190 cows producing $172 \mathrm{lb}$ fat per acre. Last season, 300 cows yielded $320 \mathrm{lb}$ fat per acre and this season 355 cows are being milked. Cows are run in one herd and milked in a 24-a-side herringbone shed. Total hay used is 5,500 bales fed at the rate of 1 bale/ 7 cows with 1 acre of saved grass, daily. Up to $1 / 2$ ton potassic superphosphate per acre is applied annually. The rainfall on this property is about 60 in. per year.

What, then, is the recipe for high production on fullydeveloped dairy farms?

( 1) High production is obtained more quickly by an increase in the carrying capacity. Initial costs for stock and fertilizer are quickly recovered. An increase in the stocking rate does not necessarily mean a drop in "per cow" production.

(2) All aspects of management must be good -milking shed techniques, especially, need to be the best.

( 3 ) Utilization_of_feed_grown_is_equally_as_important_as pasture quality, with the proviso that pastures must be reasonably productive.

(4) A balanced growth rate throughout the year from pastures is preferable to a sharply-defined seasonal 
growth, so that feed intake remains at an even level with no violent fluctuations.

(5) Stock can and must be conditioned to a lowered feed intake provided that it is kept even and does not vary too much from day to day. Much less hay can be used than many farmers realize.

(6) Too much emphasis should not be placed on cow conditions, not only in dry seasons, but also before calving.

Given the incentive, there appears to be no reason why many farmers cannot increase dairy production by 40 to $50 \%$ with little capital outlay, Such an increase would go far towards reaching the targets set by the Agricultural Development Conference.

\section{DISCUSSION}

Is a stocking rate of $1 \%$ cows per acre high enough?

A higher rate is possible. and it is planned to increase the rate to 2 cows per acre in 1967.

Does the 250 -acre property mentioned carry replacement stock on the farm?

No, all young stock arc reared off the property. This is probably economic under high carrying capacity farming.

What is the effect of low intake and high output on stock?

The high rate of stocking has little effect on mature cows, but is hard on poorly-bred young stock. Poor heifers quickly eliminate themselves.

Do poor grass species exist under- high rates of stocking?

Pcor species such as Yorkshire fog are grazed out. Poa species comprise a large proportion of pastures at ccrtain periods of the year.

A. C. Burgess: The principle of pasturc utilization is a key factor and is applicable to all districts.

What is the potential butterfat production of the West Coast?

Some farms are already, producing $275 \mathrm{lb}$ fat per acre. With adequatc drainage and fertilizer, this level can be greatly increased.

What is the reason for the decrease in herbage production at the high-stocking rate?

Possibly, the pasture measurement technique is faulty! but it is obvious. visually, that high-stocked cows have less available feed at all times.

Should supplements be fed in the spring?

At $1 \%$ cows per acre, there is no need for supplementary feeding. At 2 cows per acre, however, this may be necessary.

P. B. IYNCh 1o DR L. CORKHILL: Could improved pasture species perform better than existing species in this trial?

DR CorkHILl: When the ultimate level of production has been reached with the existing species, the new species should be introduced to assess their productive ability, with good stock under good management. 